METHODS OF ANALYSIS BY THE U.S. GEOLOGICAL SURVEY

NATIONAL WATER QUALITY LABORATORY--DETERMINATION OF ANTIMONY BY AUTOMATED-HYDRIDE ATOMIC ABSORPTION SPECTROPHOTOMETRY

By Glenda E. Brown and Betty J. McLain

U.S. GEOLOGICAL SURVEY

Open-File Report 93-664

Denver, Colorado

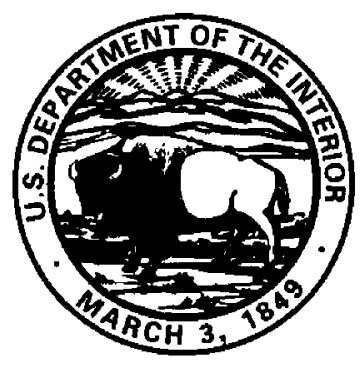




\section{U.S. DEPARTMENT OF THE INTERIOR BRUCE BABBITT, Secretary \\ U.S. GEOLOGICAL SURVEY \\ Robert M. Hirsch, Acting Director}

For additional information write to:

Copies of this report can be purchased from:

Chief, National Water Quality Laboratory

U.S. Geological Survey

U.S. Geological Survey

Books and Open-File Reports Section

Box 25046, Mail Stop 407

Box 25425

Federal Center

Federal Center

Denver, CO 80225-0425

Denver, CO 80225-0425 


\section{CONTENTS}

Page

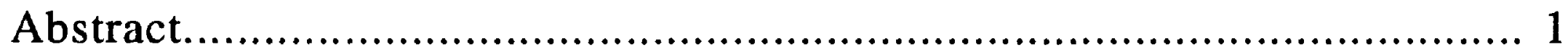

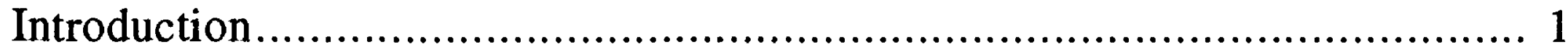

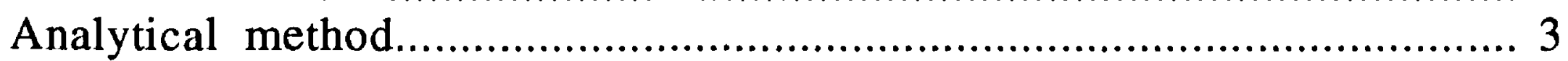

1. Application........................................................................... 3

2. Summary of method ............................................................... 3

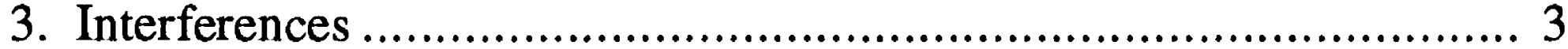

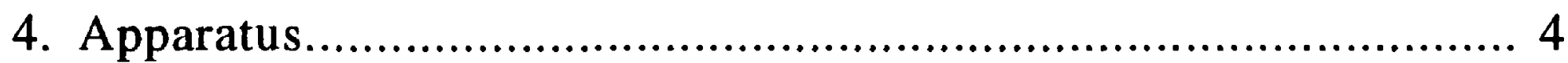

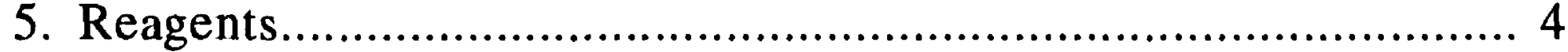

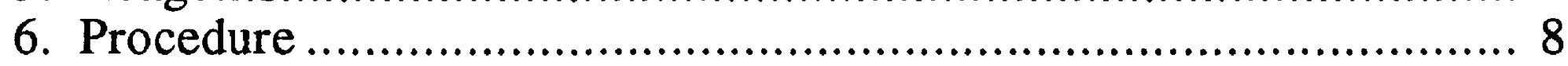

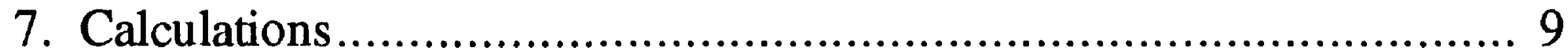

8. Reporting of results.......................................................... 9

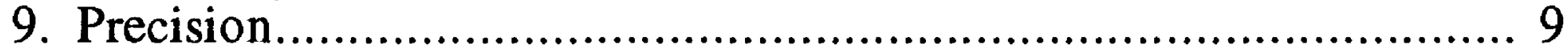

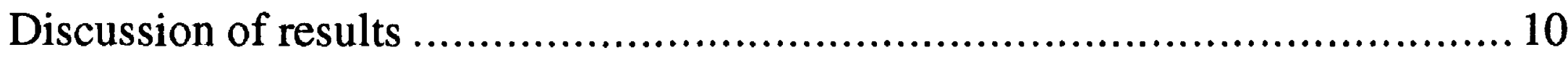

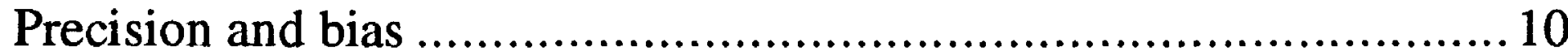

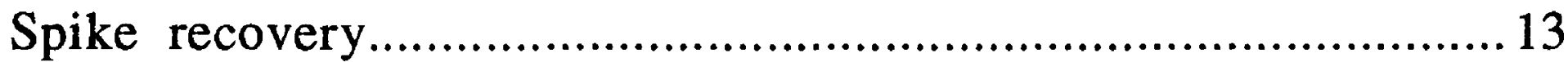

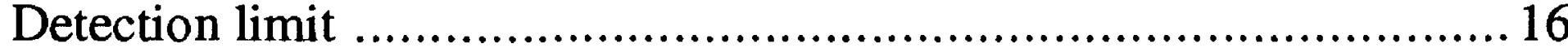

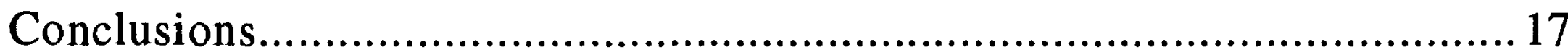

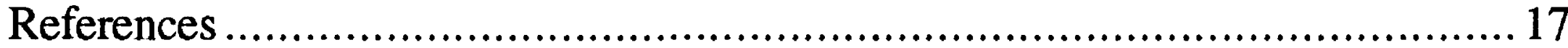

\section{FIGURES}

Figure 1. Diagram showing gas-liquid separator and quartz tube furnace ................................................................... 5

2. Schematic showing antimony manifold................................... 6

3. Graph showing relation between antimony mean concentrations determined by automated-hydride atomic absorption spectrophotometry and interlaboratory means for several Standard Reference Water Samples .....................................12

4. Graph showing antimony precision............................................. 15

\section{TABLES}

Table 1. Precision and bias of antimony method .............................11

2. Recovery of antimony in surface-water samples.................. 14

3. Sample replication listing mean, standard deviation, and relative standard deviation for four separate analyses..... 14

4. Determination of the antimony method detection limit.........16 


\section{CONVERSION FACTORS AND ABBREVIATIONS}

$\begin{array}{lcl}\text { Multiply } & B y & \text { To obtain } \\ \text { centimeter }(\mathrm{cm}) & 0.01 & \text { meter } \\ \text { gram }(\mathrm{g}) & 0.03527 & \text { ounce, avoirdupois } \\ \text { liter }(\mathrm{L}) & 0.2642 & \text { gallon } \\ \text { meter }(\mathrm{m}) & 39.37 & \text { inch } \\ \text { microgram }(\mu \mathrm{g}) & 0.000001 & \text { gram } \\ \text { micrometer }(\mu \mathrm{m}) & 0.001 & \text { millimeter } \\ \text { milliliter }(\mathrm{mL}) & 0.001 & \text { liter } \\ \text { millimeter }(\mathrm{mm}) & 0.1 & \text { centimeter } \\ \text { nanometer }(\mathrm{nm}) & 0.001 & \text { micrometer } \\ \text { pound per square inch }\left({\left.\mathrm{lb} / \mathrm{in}^{2}\right)}^{6.895}\right. & \text { kilopascal }\end{array}$

Degree Celsius $\left({ }^{\circ} \mathrm{C}\right)$ may be converted to degree Fahrenheit $\left({ }^{\circ} \mathrm{F}\right)$ by using the following equation:

$$
{ }^{\circ} \mathrm{F}=9 / 5\left({ }^{\circ} \mathrm{C}\right)+32
$$

The following units of measurement and terms also are used in this report:

$\begin{array}{ll}\text { gram per liter } & (\mathrm{g} / \mathrm{L}) \\ \text { microgram per liter } & (\mu \mathrm{g} / \mathrm{L}) \\ \text { milliliter per minute } & (\mathrm{mL} / \mathrm{min}) \\ \text { millivolts } & (\mathrm{mV}) \\ \text { molarity } & (M) \\ \text { normality } & (N)\end{array}$

Other abbreviations are as follows:

AAS atomic absorption spectrophotometry

ASTM American Society for Testing and Materials

ICP inductively coupled plasma

MDL method detection limit

MPV most probable value

NPDES National Pollutant Discharge Elimination System

NWQL National Water Quality Laboratory

SRWS Standard Reference Water Sample

USGS U.S. Geological Survey 


\title{
METHODS OF ANALYSIS BY THE U.S. GEOLOGICAL SURVEY NATIONAL WATER QUALITY LABORATORY--DETERMINATION OF ANTIMONY BY AUTOMATED-HYDRIDE ATOMIC ABSORPTION SPECTROPHOTOMETRY
}

\author{
By Glenda E. Brown and Betty J. McLain
}

\begin{abstract}
The analysis of natural-water samples for antimony by automated-hydride atomic absorption spectrophotometry is described. Samples are prepared for analysis by addition of potassium persulfate and hydrochloric acid followed by an autoclave digestion. After the digestion, potassium iodide and sodium borohydride are added automatically. Antimony hydride (stibine) gas is generated, then swept into a heated quartz cell for determination by atomic absorption spectrophotometry.
\end{abstract}

Precision and accuracy data are presented. Results obtained on Standard Reference Water Samples agree with means established by interlaboratory studies. Spike recoveries for actual samples range from 90 to 114 percent. Replicate analyses of water samples of varying matrices give relative standard deviations from 3 to 10 percent.

\section{INTRODUCTION}

Antimony is a metallic element occasionally found in low concentrations in natural water. It is often used in the semiconductor industry and can serve as a tracer element in hydrogeologic systems for gold deposits, or as a pollution indicator. Determination of antimony also is required by the U.S. Environmental Protection Agency for National Pollutant Discharge Elimination System (NPDES) permits.

Determination of antimony by conventional air-acetylene flame atomic absorption spectrophotometry (AAS) is particularly difficult. The resonance wavelength of antimony is in the low ultraviolet region of the spectrum, where absorbance from the acetylene in the flame can occur. Analysis of stibine (antimony hydride or $\mathrm{H}_{3} \mathrm{Sb}$ ) in a heated quartz cell, after hydride generation AAS, removes these interferences and provides lower detection limits than either flame AAS or inductively coupled plasma atomic emission spectrophotometry. 
In hydride generation AAS, the gaseous hydride is chemically produced by adding sodium borohydride to the sample (Andreae and others, 1981, p. 17661771). The gas is carried by a nitrogen purge into a heated quartz cell. When the stibine gas is atomized in the cell, a peak absorbance signal is produced with the height being proportional to the amount of analyte in the sample.

Water samples received by the National Water Quality Laboratory (NWQL) for analysis of metals are preserved to a pH of less than two using nitric acid to prevent loss of metals from solution. Digestion of the sample with potassium persulfate with heat under pressure decomposes any organically bound antimony. A subsequent reduction step, the addition of potassium iodide to the sample, guarantees that all of the antimony is present in the +3 valence state. Following the valence-state adjustment, sodium borohydride $\left(\mathrm{NaBH}_{4}\right)$ and hydrochloric acid $(\mathrm{HCl})$ are added to produce stibine. The stibine is swept, using an inert gas purge, through a gas-liquid separator into a heated $\left(800^{\circ} \mathrm{C}\right)$ quartz cell. There, the stibine molecules are decomposed to atomic vapor, and an absorbance signal is produced proportional to the antimony concentration in the sample.

This report describes a method for determining antimony in samples of natural water containing at least $1 \mu \mathrm{g} / \mathrm{L}$ using automated-hydride AAS. The method supplements other methods of the U.S. Geological Survey (USGS) for determination of inorganic substances in water that are described by Fishman and Friedman (1989). This method was implemented in the NWQL in 1979. 


\title{
ANALYTICAL METHOD
}

\author{
Parameters and Codes: \\ Antimony, dissolved, I-2055 $(\mu \mathrm{g} / \mathrm{L}$ as $\mathrm{Sb}): 01095$ \\ Antimony, suspended recoverable, I-7055 $(\mu \mathrm{g} / \mathrm{L}$ as $\mathrm{Sb}): 01096$ \\ Antimony, whole water recoverable I-4055 $(\mu \mathrm{g} / \mathrm{L}$ as $\mathrm{Sb}): 01097$
}

\section{Application}

1.1 This method may be used to analyze water and water-suspended sediment containing at least $1 \mu \mathrm{g} / \mathrm{L}$ of antimony. Samples containing antimony concentrations greater than $20 \mu \mathrm{g} / \mathrm{L}$ need to be diluted.

1.2 Suspended recoverable antimony is calculated by subtracting dissolved antimony from whole water recoverable antimony.

1.3 Whole water recoverable antimony in samples of water-suspended sediment may be determined after each sample has been thoroughly mixed by vigorous shaking, and a suitable portion of sample has been rapidly withdrawn from the mixture.

\section{Summary of method}

Organic antimony-containing compounds are decomposed by a potassium persulfate and hydrochloric acid digestion. The resultant decomposition products, along with inorganic antimony originally present, react with potassium iodide, hydrochloric acid, and finally with sodium borohydride to form stibine. The stibine is stripped from solution with the aid of nitrogen and then reduced to antimony atoms in a tube furnace placed in the optical path of an atomic absorption spectrophotometer at $217.6 \mathrm{~nm}$.

\section{Interferences}

3.1 A number of ions, especially transition metal cations, interfere with borohydride reductions. In most natural water, concentrations of metal cations are several orders of magnitude below the levels causing interference (Andreae and others, 1981).

3.2 Absence of interferences from selenium and arsenic (which also form gaseous hydrides) was verified at concentrations of $100 \mu \mathrm{g} / \mathrm{L}$. Higher concentrations were not tested. 


\section{Apparatus}

4.1 Atomic absorption spectrophotometer and recorder.

4.2 Refer to manufacturer's manual to optimize instrument for the following:

Grating...................................................ttraviolet

Wavelength.......................................217.6 nm

Source (electrodeless discharge lamp)..........Antimony

4.3 Autotransformer, variable; Superior ${ }^{1}$ powerstat type 3 PN1010 or equivalent.

4.4 Pyrometer, portable, 0 to $1,200^{\circ} \mathrm{C}$; Thermolyne Model PM-20700 or equivalent.

4.5 Gas-liquid separator, Pyrex, packed with 3- to 5-mm Pyrex beads (fig. 1). Cooling of the condensing column to $4^{\circ} \mathrm{C}$ is required. The nitrogen gas flow rate is adjusted for maximum sensitivity by analyzing a series of identical standards. An optimum flow rate usually ranges from 100 to $150 \mathrm{~mL} / \mathrm{min}$.

4.6 Tube furnace, quartz, $10-\mathrm{mm}$ inside diameter $\mathrm{x} 100-\mathrm{mm}$ length with a quartz eyelet at each end of the tube to anchor nickel-chrome wire and tube fused to the center with a 2-mm inside diameter quartz tube. Wrap the tube furnace with approximately $5.5 \mathrm{~m}(18 \mathrm{ft})$ of 26-gage nickel-chrome wire and cover with an insulating ceramic fiber cloth. Mount lengthwise in the optical path of the atomic absorption spectrophotometer.

4.7 Technicon AutoAnalyzer II, consisting of sampler with a manifold and a proportioning pump (fig. 2).

\section{Reagents}

5.1 Water: All references to water shall be understood to mean ASTM Type I reagent water (American Society for Testing and Materials, 1991).

${ }^{1}$ The use of trade, brand, and firm names in this report is for identification purposes only and does not constitute endorsement by the U.S. Geological Survey. 


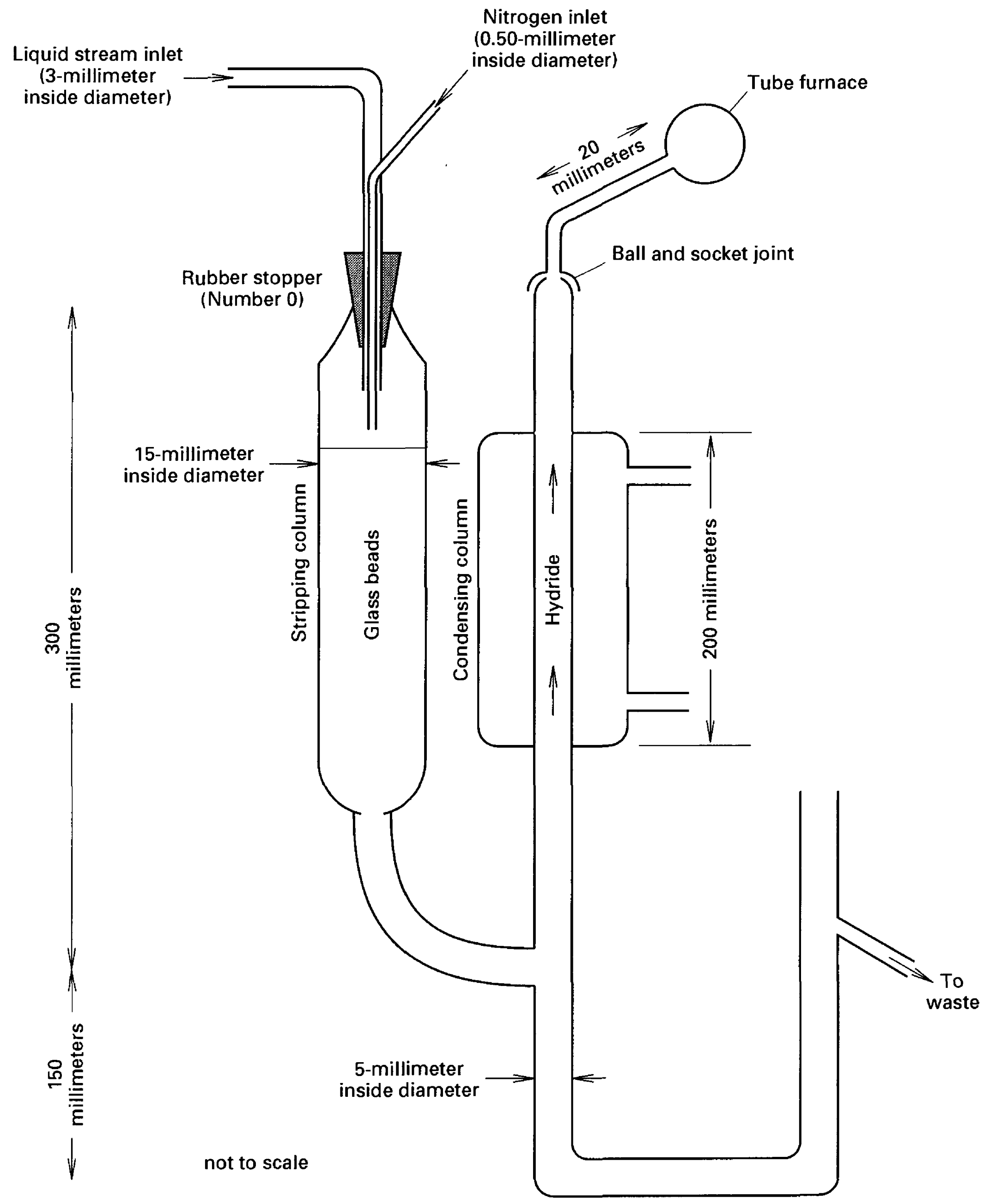

Figure 1.-Gas-liquid separator and quartz tube furnace. 


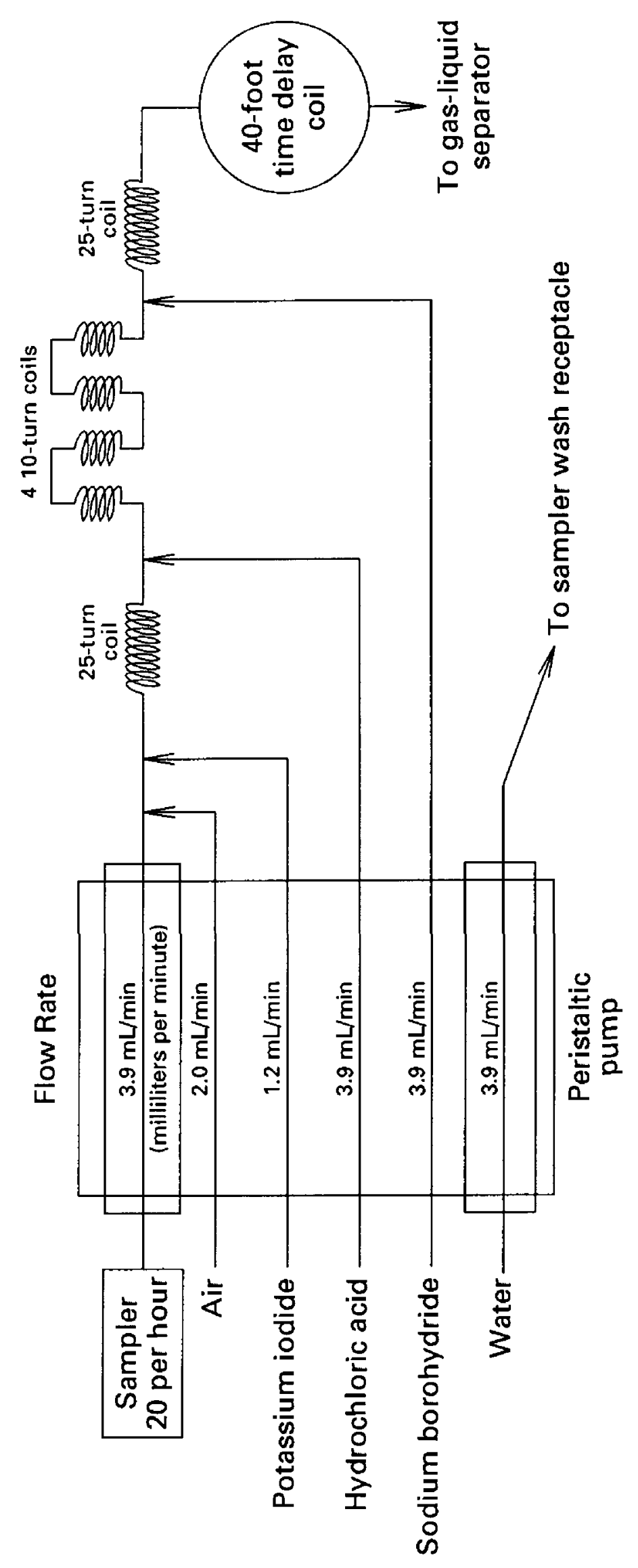

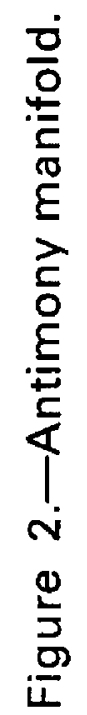


5.2 Antimony standard solution $I, 1.00 \mathrm{~mL}=100 \mu \mathrm{g} \mathrm{Sb}$. Dissolve 0.100 $\mathrm{g} \mathrm{Sb}$ metal (99.999 percent) in a minimum amount of aqua regia made from ultrapure acids. Add water to increase rate of dissolution, and dilute to $1,000 \mathrm{~mL}$ with water. As an alternative, a commercially prepared standard solution may be used and diluted accordingly.

5.3 Antimony standard solution II, $1.00 \mathrm{~mL}=10.0 \mu \mathrm{g}$ Sb. Dilute 50.0 $\mathrm{mL}$ antimony standard solution I to $500.0 \mathrm{~mL}$ with water.

5.4 Antimony standard solution $I I I, 1.00 \mathrm{~mL}=1.0 \mu \mathrm{g}$ Sb. Dilute 50.0 $\mathrm{mL}$ antimony standard solution II to $500.0 \mathrm{~mL}$ with water.

5.5 Antimony working standards. Prepare a blank and 1,000 mL each of a series of antimony working standards by appropriate dilution of antimony standard solution III with water. Each standard should also contain 0.4 percent concentrated $\mathrm{HNO}_{3}$ by volume.

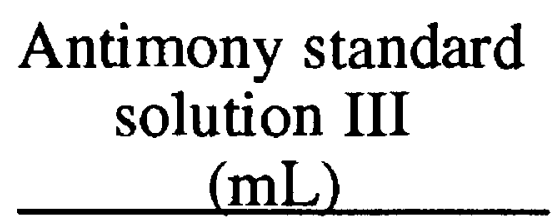

1

3

5

10

20

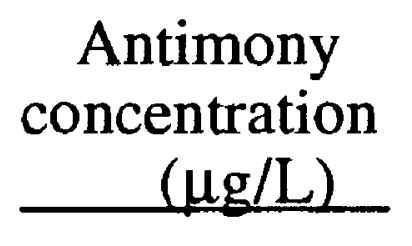

1

3

5

10

20

5.6 Hydrochloric acid, 12M, concentrated (specific gravity 1.19).

NOTE: All chemicals are reagent grade purity unless otherwise specified.

5.7 Hydrochloric acid, 6M. Add $500 \mathrm{~mL}$ concentrated $\mathrm{HCl}$ (specific gravity 1.19 ) to water, and dilute to $1 \mathrm{~L}$.

5.8 Potassium persulfate solution, $18 \mathrm{~g} / \mathrm{L}$. Dissolve $18 \mathrm{~g} \mathrm{~K}_{2} \mathrm{~S}_{2} \mathrm{O}_{8}$ in water, and dilute to $1 \mathrm{~L}$.

5.9 Potassium iodide solution, $100 \mathrm{~g} / \mathrm{L}$. Dissolve $100 \mathrm{~g} \mathrm{KI}$ in water, and dilute to $1 \mathrm{~L}$.

5.10 Sodium borohydride solution, $5 \mathrm{~g} / \mathrm{L}$. Dissolve $5 \mathrm{~g} \mathrm{NaBH}_{4}$ and $40 \mathrm{~g}$ $\mathrm{NaOH}$ in water, and dilute to $1 \mathrm{~L}$. 


\section{Procedure}

6.1 Pipet a volume of well-mixed sample containing less than $0.400 \mu \mathrm{g}$ $\mathrm{Sb}(20 \mathrm{~mL}$ maximum) into a $20-\mathrm{x} 150-\mathrm{mm}$ borosilicate test tube.

6.2 Pipet $20-\mathrm{mL}$ blanks, standard reference materials, and a complete set of standard solutions containing from 1 to $20 \mu \mathrm{g} / \mathrm{L}$ antimony into $20-\mathrm{x} 150-\mathrm{mm}$ test tubes.

6.3 Add $3.0 \mathrm{~mL} \mathrm{~K}_{2} \mathrm{~S}_{2} \mathrm{O}_{8}$ solution and $1.0 \mathrm{~mL}$ of concentrated $\mathrm{HCl}$ to each test tube. Cover tubes with plastic caps, and autoclave at $11 \mathrm{lb} / \mathrm{in}^{2}$ at $115^{\circ} \mathrm{C}$ for 20 minutes.

6.4 Set up analytical manifold as shown in figure 2.

6.5 Using a variable autotransformer, apply voltage as needed to the tube furnace to maintain a constant temperature of $800^{\circ} \mathrm{C}$. Calibrate the tube furnace temperature using a portable pyrometer with the thermocouple placed in the middle of the tube.

6.6 Feed all reagents through the system, using water in the sample line.

6.7 Condition the tube furnace by running two aliquots of a $40-\mu \mathrm{g} / \mathrm{L}$ undigested standard, followed by six aliquots of a $20-\mu \mathrm{g} / \mathrm{L}$ undigested standard.

6.8 With a $10-\mathrm{mV}$ recorder, $20 \mu \mathrm{g} / \mathrm{L}$ of antimony will give a peak approximately 60 percent of full scale. If the sensitivity drops by 30 percent or more, replace the tube furnace or treat it by swabbing the furnace with hydrofluoric acid, followed by water rinses. (CAUTION: Follow appropriate laboratory safety procedures when using hydrofluoric acid.)

6.9 Set up sample tray to be analyzed. Place digested standards in tray after beginning with a blank sample. Place individual digested standards, blanks, or Standard Reference Water Samples of varying concentrations about every eight positions; then fill the remainder of the tray with unknown digested samples.

6.10 Remove the sample line from the wash solution when the baseline stabilizes, and begin the analysis. 


\section{Calculations}

7.1 Prepare an analytical curve by plotting the height of each standard peak against its respective antimony concentration. This curve may be generated using an appropriate computer program. A second-order polynomial function $\left(y=a x^{2}+b x+c\right)$ usually provides improved concentration estimates than does the more conventional linear model $(y=m x+b)$.

7.2 Determine the concentration of dissolved or whole water recoverable antimony in each sample by comparing its peak height to the analytical curve. Any baseline drift is taken into account when computing the height of a sample or standard peak.

7.3 To determine the concentration of suspended recoverable antimony, subtract concentration of dissolved antimony from the concentration of whole water recoverable antimony.

\section{Reporting of results}

Report antimony, dissolved (01095), whole water recoverable (01097), and suspended recoverable (01096), concentrations as follows: concentrations less than $10 \mu \mathrm{g} / \mathrm{L}$ are reported to the nearest microgram per liter; results greater than or equal to $10 \mu \mathrm{g} / \mathrm{L}$ are reported to two significant figures.

\section{Precision}

9.1 Precision expressed in terms of percent relative standard deviation for dissolved antimony for 20 replicate analyses, by one operator, is as follows:

\begin{tabular}{|c|c|c|}
\hline $\begin{array}{l}\text { Mean } \\
(\mu \mathrm{g} / \mathrm{L})\end{array}$ & $\begin{array}{c}\text { Standard deviation } \\
(\mu \mathrm{g} / \mathrm{L})\end{array}$ & $\begin{array}{l}\text { Relative standard deviation } \\
\text { (percent) }\end{array}$ \\
\hline 1.6 & 0.33 & 20.7 \\
\hline 3.4 & .35 & 10.3 \\
\hline 4.6 & .58 & 12.5 \\
\hline 10.3 & 1.05 & 10.2 \\
\hline
\end{tabular}


9.2 Precision expressed in terms of percent relative standard deviation for whole water recoverable antimony for eight replicate analyses, by one operator, is as follows:

\begin{tabular}{|c|c|c|}
\hline $\begin{array}{l}\text { Mean } \\
(\mu \mathrm{g} / \mathrm{L})\end{array}$ & $\begin{array}{c}\text { Standard deviation } \\
(\mu \mathrm{g} / \mathrm{L})\end{array}$ & $\begin{array}{l}\text { Relative standard deviation } \\
\text { (percent) }\end{array}$ \\
\hline 1.4 & 0.29 & 20.9 \\
\hline 1.5 & .12 & 8.3 \\
\hline 2.0 & .28 & 14.1 \\
\hline 12.0 & .37 & 3.1 \\
\hline
\end{tabular}

\section{DISCUSSION OF RESULTS}

\section{Precision and Bias}

U.S. Geological Survey Standard Reference Water Samples (SRWS) were used to evaluate the precision of the method for determining antimony by automated-hydride atomic absorption spectrophotometry. Precision data for seven different SRWS's are listed in table 1. Replicate analyses were performed on each sample over a period of several days. An indication of the bias of the method, as well as antimony values determined by interlaboratory studies, are also listed in table 1. 
Table 1.--Precision and bias of antimony method

[NWQL, National Water Quality Laboratory; SRWS, Standard Reference Water Sample of the Branch of Quality Assurance; AAS, atomic absorption spectrophotometry; $\mu \mathrm{g} / \mathrm{L}$, micrograms per liter; n, number of replicates; --, no data]

\begin{tabular}{|c|c|c|c|c|c|c|c|}
\hline \multirow[b]{2}{*}{ SRWS } & \multicolumn{4}{|c|}{$\begin{array}{c}\text { NWQL } \\
\text { automated-hydride AAS }\end{array}$} & \multicolumn{3}{|c|}{$\begin{array}{l}\text { Interlaboratory SRWS } \\
\text { program }\end{array}$} \\
\hline & $\begin{array}{l}\text { Mean } \\
(\mu \mathrm{g} / \mathrm{L})\end{array}$ & $\mathrm{n}$ & $\begin{array}{c}\text { Standard } \\
\text { deviation } \\
(\mu \mathrm{g} / \mathrm{L})\end{array}$ & $\begin{array}{c}\text { Relative } \\
\text { standard } \\
\text { deviation } \\
\text { (percent) }\end{array}$ & $\begin{array}{c}\text { Mean } \\
(\mu \mathrm{g} / \mathrm{L})\end{array}$ & $\begin{array}{c}\text { Standard } \\
\text { deviation } \\
(\mu \mathrm{g} / \mathrm{L})\end{array}$ & $\begin{array}{l}\text { Relative } \\
\text { standard } \\
\text { deviation } \\
\text { (percent) } \\
\end{array}$ \\
\hline 93 & 1.7 & 16 & 0.4 & 23.5 & 1.2 & 0.5 & 41.7 \\
\hline 97 & 12.5 & 21 & .7 & 5.2 & 11.3 & 2.0 & 17.7 \\
\hline 99 & 4.1 & 18 & .6 & 13.7 & 3.4 & 1.4 & 41.2 \\
\hline 101 & 10.6 & 20 & 1.1 & 10.2 & 10.4 & 1.4 & 13.5 \\
\hline 103 & 9.4 & 18 & 1.0 & 10.2 & 9.4 & .5 & 5.3 \\
\hline 105 & 5.4 & 18 & .7 & 13.7 & 4.6 & 14.4 & -- \\
\hline 107 & 12.0 & 21 & .8 & 6.8 & 10.1 & $1_{2.5}$ & -- \\
\hline
\end{tabular}
methods.

${ }^{1}$ Pseudosigma values--USGS Branch of Quality Assurance changed statistical reporting

The automated-hydride AAS means generally agree with the means obtained by interlaboratory analysis, and the results all fall within one standard deviation of the interlaboratory mean value. The percent relative standard deviations range from 5 to 24 percent. These data also are shown in figure 3 . In addition, the precision of the automated technique is substantially better than the manual method (13-50 percent relative standard deviation) as reported by Fishman and Friedman (1989, p. 69).

The Student's t-test indicated a statistically significant difference at the 95percent level between the interlaboratory means and the hydride AAS means for several of the SRWS. Those differences may be attributed to the one-laboratory, one-operator, one-method operation for the automated-hydride system compared to the multiple laboratory, multiple operator, multiple methods (flame AAS, ICP, and manual hydride) used in determining the interlaboratory most probable value (MPV). The differences between the automated-hydride values and interlaboratory MPVs become much less significant when considering the precision of the method and the reporting limit (nearest microgram per liter for values less than $10 \mu \mathrm{g} / \mathrm{L}$, and two significant figures for values at or greater than $10 \mu \mathrm{g} / \mathrm{L})$. 


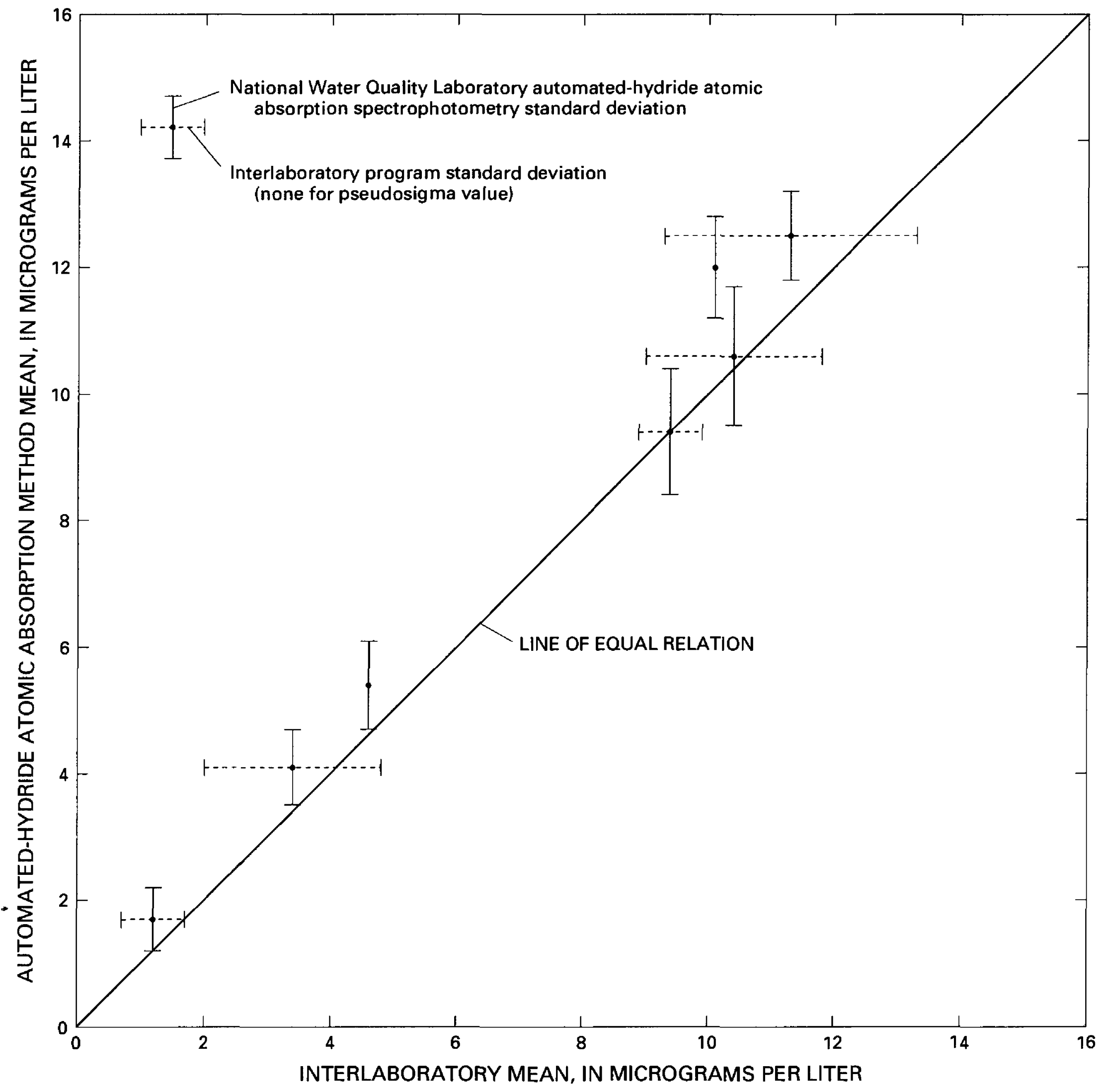

Figure 3.--Relation between antimony mean concentrations determined by automated-hydride atomic absorption spectrophotometry and interlaboratory means for several Standard Reference Water Samples. 


\section{Spike Recovery}

To further determine the accuracy of this method, 17 natural-water samples and blanks were spiked with known concentrations of antimony, then prepared and analyzed according to the automated-hydride AAS method. The results from the spike study are listed in table 2 . Recoveries ranged from 90 to 114 percent.

The spike recovery studies on the 17 blanks and samples were repeated four times to give another measure of the precision of the method. Replicate data are listed in table 2 , indicating percent relative standard deviations in the 3- to 10 -percent range, depending on concentration.

Replicate samples also were prepared and analyzed on four separate days to give an additional measure of method repeatability on actual sample matrices. These data are listed in table 3 and shown in figure 4 . Again, for actual samples with varying antimony concentrations (dissolved and whole water recoverable), the percent relative standard deviations range from 3 to 10 percent. For samples near the detection limit of $1 \mu \mathrm{g} / \mathrm{L}$, the precision decreases, with percent relative standard deviations in the 20 - to 50 -percent range. 
Table 2.--Recovery of antimony in surface-water samples

$[\mu \mathrm{g} / \mathrm{L}$, micrograms per liter]

\begin{tabular}{|c|c|c|c|c|c|c|}
\hline \multirow[b]{2}{*}{$\begin{array}{l}\text { Sample } \\
\text { number }\end{array}$} & \multicolumn{3}{|c|}{ Mean results, in $\mu \mathrm{g} / \mathrm{L}$} & \multirow[b]{2}{*}{$\begin{array}{l}\text { Percent } \\
\text { recovery }\end{array}$} & \multirow{2}{*}{$\begin{array}{c}\text { Standard } \\
\text { deviation } \\
(\mu \mathrm{g} / \mathrm{L})\end{array}$} & \multirow{2}{*}{$\begin{array}{l}\text { Relative } \\
\text { standard } \\
\text { deviation } \\
\text { (percent) }\end{array}$} \\
\hline & Present & Added & Found & & & \\
\hline Blank & 0 & 5 & 5.0 & 100 & 0.29 & 5.8 \\
\hline Blank & 0 & 5 & 5.1 & 102 & .2 & 3.9 \\
\hline Blank & 0 & 10 & 10.6 & 106 & .62 & 5.9 \\
\hline Blank & 0 & 5 & 5.7 & 114 & .36 & 6.3 \\
\hline 1 & .2 & 10 & 10.7 & 105 & .35 & 3.3 \\
\hline 2 & .5 & 10 & 11.6 & 110 & .78 & 6.7 \\
\hline 3 & .7 & 10 & 9.9 & 93 & .36 & 3.6 \\
\hline 4 & 1.2 & 10 & 12.8 & 114 & .71 & 5.6 \\
\hline 5 & 1.7 & 5 & 6.9 & 103 & .28 & 4.1 \\
\hline 6 & 1.8 & 10 & 12.3 & 104 & .45 & 3.6 \\
\hline 7 & 2.7 & 10 & 12.6 & 99 & .81 & 6.4 \\
\hline 8 & 3.7 & 5 & 9.9 & 114 & .54 & 5.4 \\
\hline 9 & 4.7 & 10 & 13.2 & 90 & 1.32 & 10.0 \\
\hline 10 & 5.4 & 10 & 14.9 & 97 & 1.21 & 8.1 \\
\hline 11 & 5.8 & 10 & 15.0 & 95 & .96 & 6.4 \\
\hline 12 & 10.7 & 5 & 16.4 & 104 & .84 & 5.1 \\
\hline 13 & 12.3 & 5 & 16.4 & 95 & .87 & 5.0 \\
\hline
\end{tabular}

Table 3.--Sample replication listing mean, standard deviation, and relative standard deviation for four separate analyses

$[\mu \mathrm{g} / \mathrm{L}$, micrograms per liter]

\begin{tabular}{cccc}
\hline $\begin{array}{l}\text { Sample } \\
\text { number }\end{array}$ & $\begin{array}{c}\text { Mean } \\
(\mu \mathrm{g} / \mathrm{L})\end{array}$ & $\begin{array}{l}\text { Standard } \\
\text { deviation } \\
(\mu \mathrm{g} / \mathrm{L})\end{array}$ & $\begin{array}{c}\text { Relative standard } \\
\text { deviation (percent) }\end{array}$ \\
\hline & & & \\
2 & 1.2 & 0.55 & 47.4 \\
3 & 12.2 & .43 & 3.5 \\
4 & 5.8 & .27 & 4.6 \\
5 & 1.7 & .38 & 22.3 \\
6 & 1.5 & .58 & 39.4 \\
7 & 7.4 & .25 & 3.4 \\
8 & 9.7 & .64 & 6.6 \\
9 & 9.6 & .51 & 5.3 \\
10 & 8.6 & .45 & 5.2 \\
11 & 9.8 & .57 & 5.8 \\
12 & 12.3 & .46 & 3.7 \\
13 & 1.4 & .29 & 20.9 \\
\hline
\end{tabular}




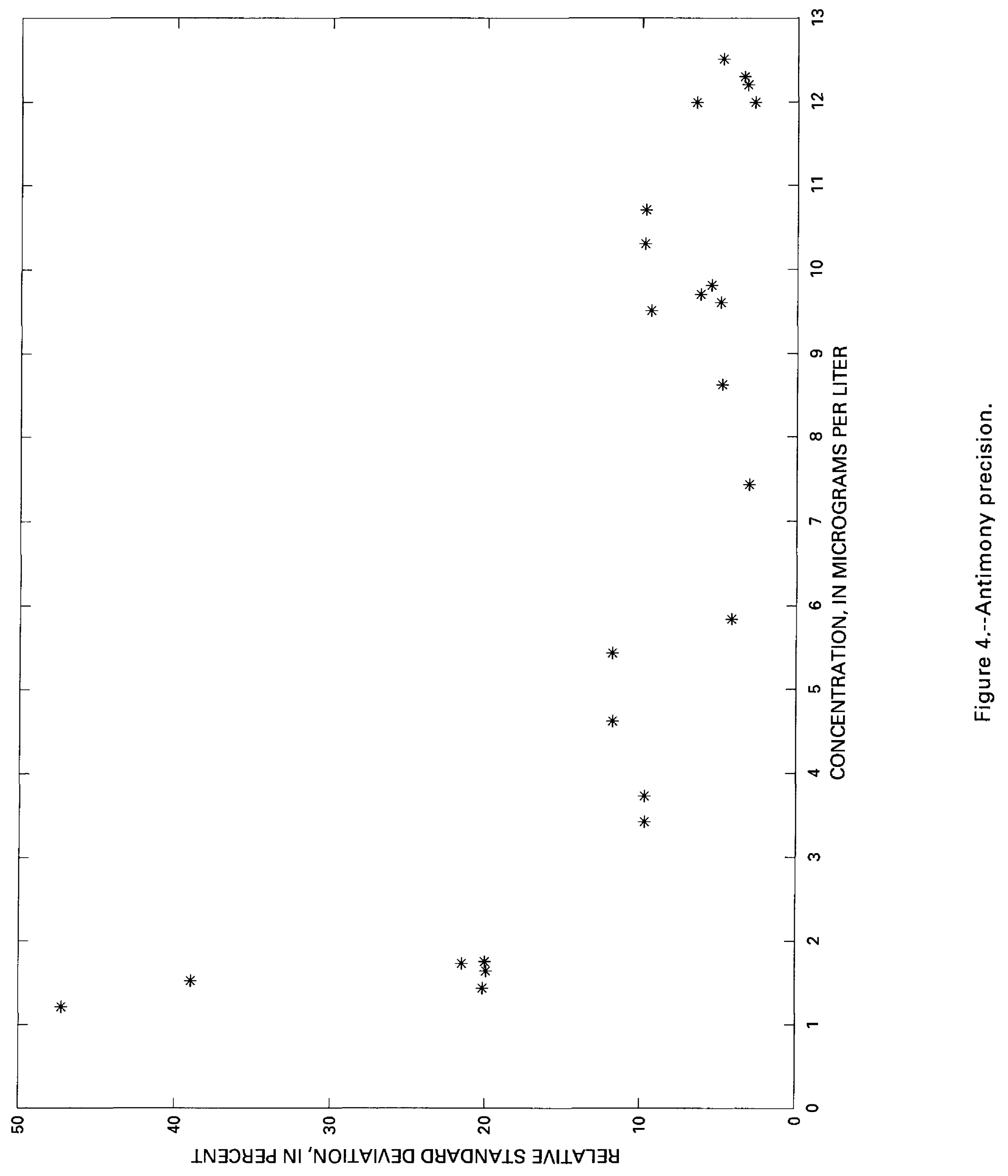




\section{Detection Limit}

The method detection limit (MDL), using the procedure from the U.S. Environmental Protection Agency (1992, p. 565-567), is defined as the minimum concentration of a substance that can be measured and reported with 99 percent confidence that the analyte concentration is greater than zero. The theoretical detection limit was determined to be $0.71 \mu \mathrm{g} / \mathrm{L}$, on the basis of three times the standard deviation of multiple blank determinations. An antimony standard was prepared with a concentration of $3 \mu \mathrm{g} / \mathrm{L}$ (approximately three times the theoretical detection limit). This standard then was analyzed ten times nonconsecutively. A mean and standard deviation were calculated from the data listed in table 4 to determine the MDL. According to the U.S. Environmental Protection Agency (1992, p. 565-567), the MDL was calculated to be $0.42 \mu \mathrm{g} / \mathrm{L}$. A reporting limit of $1 \mu \mathrm{g} / \mathrm{L}$ was chosen as appropriate for this analysis.

Table 4.--Determination of the antimony method detection limit $[\mu \mathrm{g} / \mathrm{L}$, micrograms per liter]

\begin{tabular}{cc}
\hline $\begin{array}{c}\text { Replicate } \\
\text { number }\end{array}$ & $\begin{array}{c}\text { Concentration } \\
(\mu \mathrm{g} / \mathrm{L})\end{array}$ \\
\hline 1 & \\
2 & 2.8 \\
3 & 2.8 \\
4 & 2.9 \\
5 & 2.9 \\
6 & 2.7 \\
7 & 2.7 \\
8 & 3.0 \\
9 & 2.8 \\
10 & 2.9 \\
\hline
\end{tabular}

$\begin{array}{ll}\text { Mean }(\mu \mathrm{g} / \mathrm{L}) & =2.87 \\ \text { Standard deviation }(\mu \mathrm{g} / \mathrm{L}) & =0.149 \\ \text { Number of points } & =10 \\ \text { Degrees of freedom } & =9 \\ \mathrm{t} \text { value }(99 \text { percent confidence) } & =2.821 \\ \text { Method detection limit } & =0.42\end{array}$




\section{CONCLUSIONS}

The automated-hydride atomic absorption spectrophotometric method for antimony gives reproducible and accurate results for natural-water samples. The precision and bias are equal to or better than a manually operated antimonyhydride system. The automated system also provides the operator with ease of analysis and minimizes errors from incorrect or variable reagent additions that might occur during manual-hydride AAS analysis.

\section{REFERENCES}

American Society for Testing and Materials, 1991, Annual book of ASTM standards, Section 11, Water: Philadelphia, v. 11.01, p. 36, 45, and 434.

Andreae, M.O., Asmodé, J.F., Foster, P., and Van't dack, L., 1981, Determination of antimony(III), antimony(V), and methylantimony species in natural waters by atomic absorption spectrometry with hydride generation: Analytical Chemistry, v. 53, no. 12, p. 1766-1771.

Fishman, M.J., and Friedman, L.C., eds., 1989, Methods for determination of inorganic substances in water and fluvial sediments: U.S. Geological Survey Techniques of Water-Resources Investigations, book 5, chap. A1, 545 p.

U.S. Environmental Protection Agency, 1992, Primary drinking-water regulations, maximum contaminant levels (Appendix B to part 136, National primary drinking-water regulations): U.S. Code of Federal Regulations, Title 40, parts 100-149, revised as of July 1, 1992, p. 565567. 